\title{
MIGRANT AND AUTOCHTHONOUS TRADITIONS WITHIN UDMURT FOLKSONG (ON THE EXAMPLE OF THE SIBERIAN UDMURT)
}

\author{
NIKOLAI ANISIMOV \\ Researcher \\ Institute of Philology of the Siberian Branch \\ Russian Academy of Sciences \\ 8, ul. Nikolaeva, Novosibirsk, 630090, Russian Federation \\ Researcher \\ Department of Folkloristics \\ Estonian Literary Museum \\ Vanemuise 42, 51003 Tartu, Estonia \\ e-mail: nikolai.anisimov@kirmus.ee \\ IRINA PCHELOVODOVA \\ Research Associate \\ Udmurt Institute of History, Language and Literature \\ Udmurt Federal Research Centre, Ural Department \\ Russian Academy of Sciences \\ 4, ul. Lomonosova, 426004, Izhevsk, Russian Federation \\ e-mail: orimush@mail.ru \\ EKATERINA SOFRONOVA \\ Junior Researcher \\ Institute of Philology of the Siberian Branch \\ Russian Academy of Sciences \\ 8, ul. Nikolaeva, Novosibirsk, 630090, Russian Federation \\ e-mail: soroka-katya90@yandex.ru
}

\begin{abstract}
This article* investigates, for the first time, the local musical tradition of the Udmurt of Chainsk district (Tomsk oblast). The overwhelming majority of migrants in this region arrived from the Sharkan district of the Udmurt Republic, in Siberia, at the beginning of the 20th century. For a long time they kept their original culture in an ethnically alien environment. However, at the beginning of the 21st century, their singing tradition started to fade under the influence of different factors (such as the
\end{abstract}

* This research has been supported by a grant of the Russian Science foundation (project No 19-78-10113: Folklore of Autochthonous and Migratory Traditions of Volga Region Peoples in Modern Records and Historical Dynamics: An Interactive Atlas of Audio Texts, directed by Pavel Shakhov). 
disappearance of Udmurt rituals and festivals, as well as mixed marriages). The aim of this article is to compare the 'Chainsk migrational' singing tradition to the 'Sharkan original' musical tradition. The main collection of audio recordings covering the Chainsk district Udmurt musical tradition is conserved in the archives of the Udmurt Research Institute at the Russian Academy of sciences. ${ }^{1}$ It is comprised of fieldwork material gathered by researchers from the Institute in 1974 and 2006. We discovered new sources of audio and video recordings of the singing tradition in this territory, which allowed us to integrate more song samples. The analysis of both traditions reveals the basic genres of ritual singing, each of which has been examined from the point of view of the topic of the poetic text, the mood structures, and the metro-rhythmic and melodic peculiarities of their development.

KEYWORDS: Udmurt • Siberian Udmurt • Tomsk oblast • migrants • original tradition $\bullet$ musical folklore $\bullet$ comparative analysis

The territory of the Volga and Kama basins is characterised by the coexistence of different ethnic groups, which are very significant for Russia. However, during the 20th century, the high level of migration within the country, due to political, economic, natural and climatic factors, allowed the spreading of the Volga and Kama peoples' traditional cultures into Siberian territory, where the migrants created compact hearths of FinnoUgric and Turkic cultures. Among them are the Udmurt, one of the communities of Finno-Ugric-Uralic origin whose autochthonous territory is the Volga-Urals region.

In this article, we are interested in the local singing tradition of the Udmurt of Tomsk oblast, part of the Siberian Udmurt group. In a situation in which folklore traditions are continuously fading and local peculiarities are deleted, while indicators from written and media culture are being strengthened, the question of maintaining and researching ethno-cultural heritage is more and more topical. We have chosen the focus of our research because this local tradition is the one about which there is the most material from fieldwork, which allows achieving a competent analysis. This topic had not yet been an object of particular research, while some aspects of the traditional culture of the Udmurt diaspora in Siberia have been investigated in other research (Korepanova 1976; Vladykin 1976; Atamanov 1982; 2004; 2008; Tuchkova 2001; Zhuravlëva and Kuznetsova 2008; Mymrina and Shitts 2019).There has been an interest in studying the traditions of Siberian immigrants since the end of the 19th century, and this topic is no less present today, as shown by the quantity of articles dedicated to different ethnic groups that, for different reasons, have migrated to Siberia (Dayneko 2017; Leonova 2017; Shakhov 2017; Ismagilova 2018). Moreover, researchers at the Department of Folklore of the Peoples of Siberia at the Philology Institute of the Siberian Section of the Russian Academy of Sciences, as well as ethnomusicologists at the M. I. Glinka State Conservatory of Novosibirsk, elaborated in 2014, within a project of the Russian human science foundation, a new theoretical approach to the study of singing traditions of autochthonous and migrating peoples of Siberia. The main idea was a unified research programme for nonkindred peoples, with an analysis of singing traditions in Siberia (Leonova et al. 2015). Thus, our approach in this article is encompassed within a problematic much demanded in contemporary human sciences. The main sound collection of audio-recordings from the musical tradition of Udmurt from Tomsk oblast is conserved in the archives of the Udmurt Institute of History, Language and Literature of the Udmurt Federal Research 
Centre of the Ural Department of the Russian Academy of Sciences (below UIHLL UdmFRC Ud RAS). These are records from fieldwork in 1974 and 2006. We also discovered other sources of singing material. Natal'ya Anatol'yevna Tuchkova's bequest is kept in the Mikhail Bonifat'yevich Shatilov local history museum in Tomsk oblast. A video recording of Andrey Filimonov was arranged by Tomsk television channel TV2 in 2003 (UIHLL 2003, VR 219). Thus, the aim of this article is to describe the singing tradition of the Siberian Udmurt from Chainsk district and to make a comparative analysis with the musical folklore of the original tradition. The methodology used arises from the aim of the research, taking into account philological and musicology approaches. The former includes an analysis of the themes and topics of the poetic texts, the latter reveals the composition (poetically and musically), the structures, and the metric, rhythmic and melodic peculiarities of the evolution.

\section{THE HISTORY OF UDMURT MIGRATION TO SIBERIA}

The first Udmurt settlements in Siberia appeared at the end of the 19th century. The migration movement peaked at the beginning of the 20th century (1910-1912), in connection with the implementation of Pëtr Arkad'yevich Stolypin's agrarian reform.

One of the most significant problems in the Russian Empire at the beginning of the 20th century was what was called 'land hunger'. Most of the land in eastern Russia was very weakly exploited. Therefore, Stolypin's reform set as one of its main goals the displacement of peasants from the western administrative areas to eastern, mainly beyond the Urals. These changes were supposed to concern those peasants who did not have land of their own. These peasants 'without land' were supposed to relocate beyond the Urals in order to create their own homesteads. This process was voluntary, and the government did not compel any of the peasants to relocate. Moreover, the relocation policy relied on the idea of giving peasants willing to go beyond the Urals as much benefit as possible, and good living conditions. Thus, a person willing to migrate received several benefits: the farm was free of any taxes for five years; the peasants received the land as their own (given according to the following calculation: 15 ha for a farm, and 45 ha for each member of the family); and finally each migrant was guaranteed cheap loans, the amount depending on the region but in some places this was 400 roubles, a huge amount in the Russian Empire. In each region 200 roubles was given with no need of repayment with the rest considered a loan. Men who established a farm were free of the obligation to perform military service. (Agrarnaya reforma) These were the main reasons why some people undertook the long and harsh migration to Siberia, the majority of whom came from the present Sharkan district of the Udmurt Republic (below UR). Only one village (Tiga IV, in Udmurt Uyvay - no longer extant) was founded by migrants from Uyvay and the surrounding villages of today's Debësy district, UR. In the 1930s, a small group of eastern Udmurt from Kuyeda district in Perm kray settled in the Chainsk district of Tomsk oblast. Because of their small number, these eastern Udmurt adapted into the Sharkan tradition and became part of it. According to the available data, in Tomsk oblast the Udmurt live in compact Udmurt settlements in Chainsk district, although they are also spread across other districts. According to the census, their number is decreasing, as Table 1 shows. 
Table 1. The dynamics of the Udmurt population in Tomsk oblast in 1970, 1979, 1989, 2002, and 2010. Presented in Mymrina and Shitts 2019: 46.

\begin{tabular}{|l|l|l|l|}
\hline Year & $\begin{array}{l}\text { Total } \\
\text { population }\end{array}$ & $\begin{array}{l}\text { Among them, } \\
\text { Udmurts }\end{array}$ & $\begin{array}{l}\text { Percent, } \\
\text { \% }\end{array}$ \\
\hline 1970 & 785,706 & 1,825 & 0.23 \\
\hline 1979 & 865,934 & 1,901 & 0.22 \\
\hline 1989 & $1,001,613$ & 1,944 & 0.19 \\
\hline 2002 & $1,046,039$ & 1,485 & 0.14 \\
\hline 2010 & $1,047,394$ & 1,081 & 0.10 \\
\hline
\end{tabular}

In addition to the gradual numerical decrease in the Udmurt population in Tomsk oblast, Dina Mymrina and Ol'ga Shitts (2019) emphasise the critical situation of the vernacular tongue, which, according to them, is a peculiar indicator of the situation of the language and culture (Table 2).

Table 2. The dynamics of Udmurt and Russian language knowledge in 1979 and in 2010. Presented in Mymrina and Shitts 2019: 46.

\begin{tabular}{|l|l|l|l|}
\hline Year & Number of Udmurt & Knowledge of Udmurt & Knowledge of Russian \\
\hline 1979 & 1,901 & 903 & 996 \\
\hline 2010 & 1,081 & 288 & 790 \\
\hline
\end{tabular}

These examples show clearly that the present Udmurt diaspora in Tomsk oblast comes mainly from two districts of Udmurtia (Sharkan and Debësy), which have assimilated a group of Udmurts from Kuyeda district, Perm oblast. Today we notice no further migration and the number of Udmurt diminishes gradually with the process of Russification.

\section{FIELDWORK IN THE SIBERIAN UDMURT VILLAGES OF TOMSK OBLAST}

Expeditions to the Siberian Udmurt in order to record their musical folklore were not achieved so often. Therefore, the material gathered in each of them is particularly precious. According to our knowledge, the earliest recordings of the Siberian Udmurt musical tradition took place in 1974, and were collected during a joint expedition by the teachers and students at the Udmurt University and the researchers at the Udmurt Scientific and Research Institute (now UIHLL UdmFRC Ud RAS). The expedition worked under the leadership of Vladimir Emelyanovich Vladykin, who was then still an associate professor, candidate in history (now professor). He took with him students, some of whom later became doctors, such as for example Galina Arkadyevna Nikitina (Korepanova), doctor in history (1951-2017), and Mikhail Gavrilovich Atamanov (professor, doctor of philology and translator of church literature into Udmurt). The results of this fieldwork led to the publication of some of the investigations. The first article was published in 1976 by Vladykin describing for the first time the Siberian Udmurt ethnographic group. Material from the expedition was the basis of graduation thesis by Nikitina (Korepanova 1976), while Atamanov (1982) dedicated an article to a sample of the Siberian Udmurt language. Many years after the expedition, Atamanov $(2004 ; 2008)$ 
published other historical and ethnographic texts in which he described the two zones of Siberian Udmurt settlement, called the Birilyussy group (Krasnoyarsk kray) and the Chainsk group (Tomsk oblast), named after the districts in which they are located. Some of this material is really precious, including photos by the members of the expedition and the lyrics of the songs (both ritual and non-ritual).

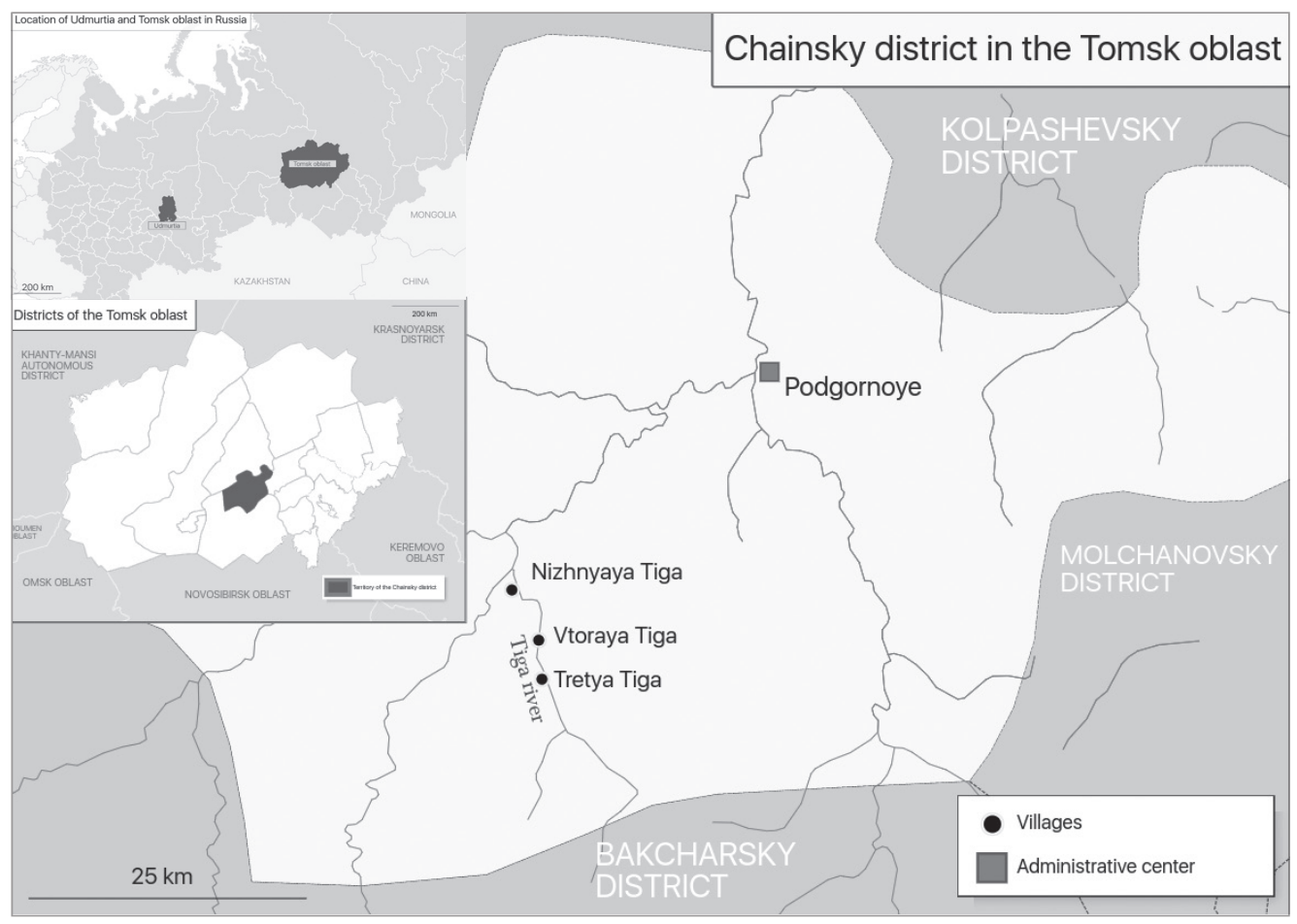

Figure 1. Chainsk District in Tomsk Oblast. Map by Nikolai Anisimov and Valentin Châtelet.

We must acknowledge the courage of this first expedition, as the members decided their route without knowing the exact location of the Udmurt villages. According to Atamanov, they were received in Tomsk oblast like precious and close relatives. ${ }^{2}$

The 1974 material includes three audio cassettes (UIHLL 1974, TR 32-34), digitised within a joint international project with the British Library in 2012-2013 (where a copy remains). ${ }^{3}$ From Tomsk oblast, there are audio-recordings of Udmurt living in three villages in the Chainsk district who have, in addition to official names, Udmurt names used by the local population.

Table 3. Names of settlements with an Udmurt population in the Chainsk district of Tomsk oblast.

\begin{tabular}{l|l} 
Official name & Udmurt name \\
\hline Tiga I & Chibysh (the clan name of the first settler) \\
\hline Tiga II & Shor Tiga ('Middle Tiga') \\
\hline Tiga III & Bil'yb (name of the village the migrants came from) \\
\hline
\end{tabular}


Participants in the 1974 fieldwork recorded 25 songs, among which seven are ritual songs (wedding, recruiting, guest songs belonging to later layers) and 18 are non-ritual (lyrical songs in Udmurt and Russian, and a fun song in Russian).

The reason why most of the songs are ritual songs is that at the time of the migration, not everybody made it to the final destination as the journey was too difficult. Many lost their parents or their children, who died of typhus. In connection with these episodes, the lyrical songs acquired a particular resonance for the Udmurt in their new homes, surrounded by the Siberian woods and full of nostalgia, as they were, for their former country. In the poetic texts, the most frequent topics are orphanage, separation from family, village community, and native space ("Like a Maple, Oh, a Green Maple...", "The Nightingale Sings...", "At Some Time, I Suppose, I Was", "I Miss My Father..."). The following recordings of the Chainsk Udmurt are from 2001. The collector is Tuchkova, senior researcher from the Tomsk Museum of Local History, now a doctor of history. Unfortunately, the sound material is not available, but, according to Tuchkova, ${ }^{4}$ there are two audio cassettes containing interviews with villagers and seven or eight songs from different genres. She relied on this material for her historical and ethnographic article "The Udmurts from Tiga" (Tuchkova 2001). As she says, the Udmurt named their villages Tiga, from the name of the river along which they were built. At the end of the article, she adds the song lyrics: one wedding song ("She Sits Alone, in Her Thoughts..."), one lyrical song ("Like a [Green] Maple...") and one table song ("Let Us Drink, Let Us Drink This Wine..."). In 2003, a film crew from Tomsk's TV-2 visited these same locations. ${ }^{5}$ They also recorded conversations with elder inhabitants of the village, some non-ritual songs ("Like a Maple, Oh, a Green Maple...", "Let Us Drink, Let Us Drink This Wine...", "The Nightingale Sings...", "Saying Goodbye, You Went Away...") and dancing songs sung by an ensemble. The video material reveals the context, the internal part of the izbas, the faces of the villagers, and, most importantly, gives a visual image of how people sang the songs, their performance and their behaviour while singing. The last trip to the Chainsk Udmurt took place in 2006 in connection with the 100th anniversary of the foundation of Tiga III. ${ }^{6}$ At that moment, only two villages were still alive, Tiga I and Tiga III. Due to the so-called optimisation, Tiga II's population was relocated at the end of the last century to neighbouring villages.

One of this article's authors, Irina Pchelovodova, was one of the members of this expedition. She says that this trip left her with warm memories of the meetings with the local Udmurt. Although many of them were born in Siberia and grew up there, they received the Udmurt delegation 'from Russia' as their kin. The faces of 'our' Siberian Udmurt - Vasilisa Petrovna Perevozchikova (born 1929), Efrosiniya Fedorovna Strelkova (born 1934), Tat'yana Pavlovna Strelkova (born 1924), and Evgeniya Aleksandrovna Perevozchikova (born 1930) - are unforgettable (see Photo 1). In spite of (or perhaps because of) the harsh climatic conditions, the Siberian Udmurt built good homesteads: the spacious streets were impressive with their width. The expedition as a whole allowed the strengthening of the connection between Udmurtia and the Udmurt in Chainsk district; in fact, they founded a local section of the All-Udmurt NGO Udmurt kenesh ('The Udmurt Council'), and the local inhabitants were happy to subscribe to Udmurt periodical publications, initiating a correspondence that lasted a long time. This elicited hope that they would not forget their historical home and roots. 


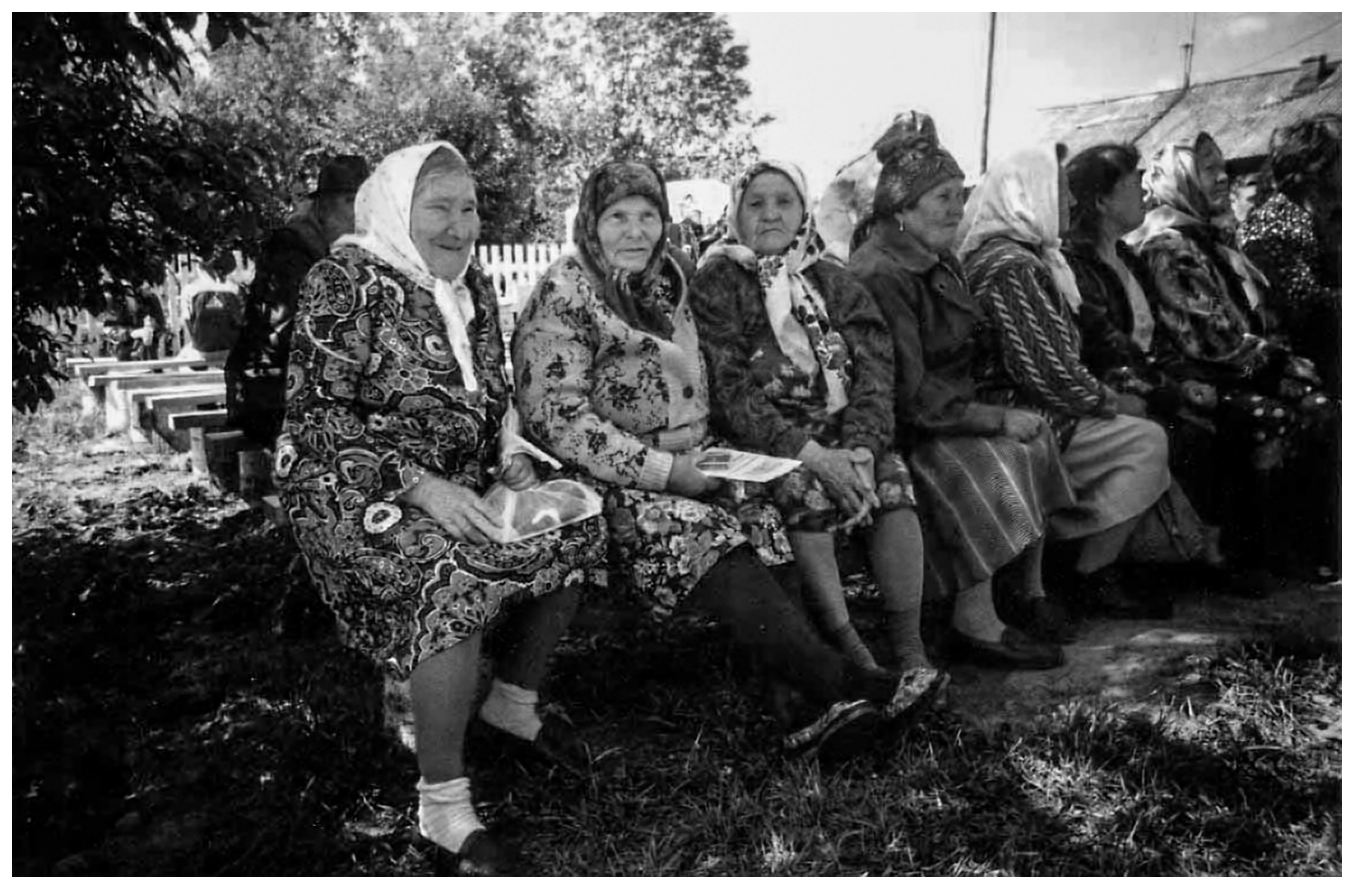

Photo 1. Celebration of the 100 years of Tiga III. From left to right: Tat'yana Strelkova, Vasilisa Perevozchikova, Evgeniya Perevozchikova. Photo by Irina Pchelovodova, June 17, 2006.

This expedition was able to record only seven songs: two ritual songs from a recent layer (the wedding song "She Sits Alone, in Her Thoughts...", the table song "Let Us Drink, Let Us Drink This Wine..."); the others are non-ritual songs, which perfectly correspond to the previous expeditions' repertoire ("Like a Maple, Oh, a Green Maple...", "At Some Time, I Suppose, I Was...", "The Nightingale Sings...", "Saying Goodbye, I Went Away..."). The reason why the expedition was able to record so few songs may be that only elder villagers spoke Udmurt (see Tables 1 and 2). The singing tradition was disappearing because of the fading of Udmurt rituals and feasts as well as the increase in mixed marriages. This is what the results of the last investigations into the linguistic situation of the Tomsk oblast Udmurt reveal:

with the increasing of contact with the local population, which is mainly Russianspeaking, and the increase in marriages between Russians and Udmurts, we have noticed a decrease in the number of people who know or actively use Udmurt in their everyday communication (Mymrina and Shitts 2019: 45).

Undoubtedly, changes in society would influence the situation of traditional culture, and, among other indicators, the situation of musical folklore:

Such ethnic songs and sayings, which in Udmurt families were carefully transmitted from generation to generation, have been forgotten. The Tiga Udmurts explain this by saying that they came to the Tomsk region to work and not to rest, and therefore their life was full of hard work, after which they had no strength for 
anything else. Thus, the songs that are sung now during festivals in the Udmurt villages of Tomsk oblast belong to a modern tradition. (Ibid.: 46)

\section{FIELDWORK IN THE SHARKAN DISTRICT OF UDMURTIA}

The Sharkan district is situated in the northeastern part of Udmurtia. We must emphasise that there is no research on the folklore tradition of this local Udmurt group. We may refer only to one work by Grigoriy Vereshchagin (1886), which describes the ethnography and the life of the Sharkan Udmurt at the end of the 19th century. Thus, this article partly fills a gap in Udmurt folkloristics.

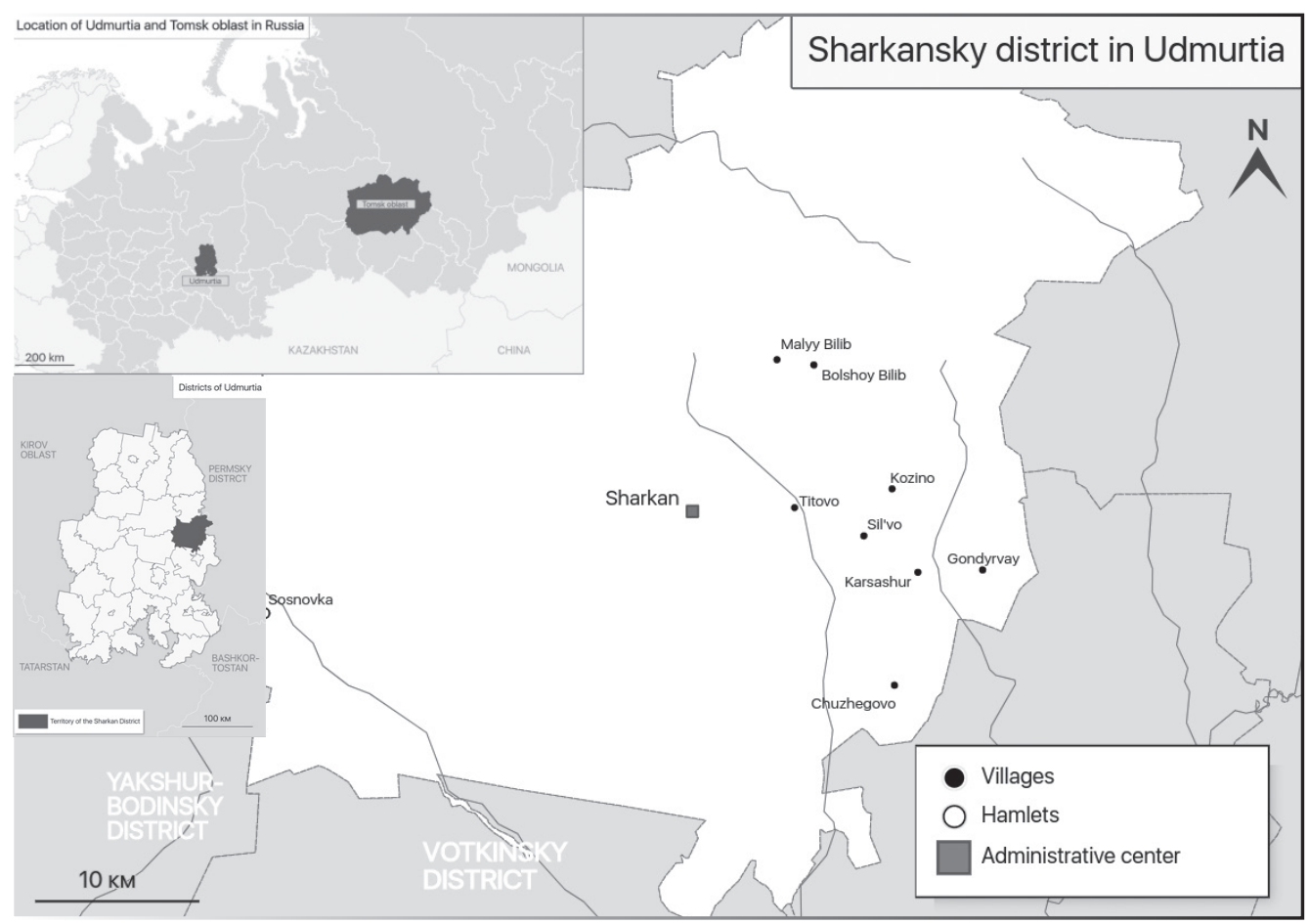

Figure 2. Sharkan district, Udmurtia. Map by Nikolai Anisimov and Valentin Châtelet.

Researchers at the UIHLL UdmFRC Ud RAS have made three folklore and ethnographic fieldwork trips to Sharkan district, in 1995 (UIHLL 1995, AC 145/1-5), 2001 (UIHLL 2001, AC 166/1-7) and 2019 (UIHLL 2019, AR 216). According to field materials and the written sources, the villages the migrants came from were Malyy and Bol'shoy Bilib, Karsashur, Chuzhegovo, Gondyrvay, Titovo, Sil'vo and Kozino. We relied on these locations as the singing material from this tradition when we came to make a comparison with Siberian examples.

The first expedition was composed of researchers and doctoral students from the Department of Literature and Folklore at the UIHLL Ud RAS: Svetlana Viktorovna 
Starodubtseva, Irina Nikolayevna Pletneva and Yuriy Aleksandrovich Perevozchikov. They investigated six villages, among which were Karsashur and Gondyrvay. They recorded a huge amount of singing material and ethnographic conversations about different rituals and festivals (for example calendar and family events, young people's entertainment, stories about wizards and flying snakes, information about people of low mythology), as well as genres of prose folklore (in Udmurt ishan, stories involving meetings with supernatural beings). The singing material from these two villages revealed a good knowledge of ritual folklore: the expedition recorded five wedding songs, two recruiting songs, a guest song, five round dances (in Udmurt and Russian) and one lyrical song. In 2001, two researchers from the Institute, Irina Murtazovna Nuriyeva from the Department of Literature and Folklore, and Nadezhda Ivanovna Shutova from the Department of Archaeological Studies, went to Sharkan district. They researched four villages, although here we are interested only in what they found in Malyy Bilib. This expedition recorded 12 musical samples of family and clan songs (wedding, recruiting and guest). The task of the last expedition in 2019, with Nuriyeva and Pchelovodova, was to record musical and ethnographic material from all the above-mentioned villages: Sil'vo, Karsashur, Gondyrvay, Chuzhegovo, Titovo, and Bol'shoy Bilib. The expedition collected 114 items, each of them representing a particular genre: conversations with local people about the origins of the villages; ethnographic narratives about rituals; and stories that include supernatural encounters or dances. In addition to this there were many singing genres, for example ritual and family songs - wedding, recruiting, guest, funeral-commemorative songs; non-ritual, lyrical songs, dancing, chastushki; loan songs from Russian musical folklore; author songs in Udmurt; songs from the Soviet period in Russian as well as their translation into Udmurt. It is interesting to note that some songs from Russian folklore appear within the frame of funeral folklore as compulsory, such as "I Went to the Forest to Gather Raspberries", "Open the Window, Open It", "I Have Closed My Eyes", "Say, Say When You'll Be Back". This phenomenon is characteristic of the folklore of northern Udmurtia. In general, we may say that the expeditions by the Sharkan Udmurt reveal rich singing material for family rituals. Some phenomena connect Sharkan Udmurt tradition with the musical folklore of the northern Udmurt. There is a good variety of ethnographic narratives about local rituals. We must highlight the Sharkan Udmurt love of the ishan genre (around 20 songs). The informants say that in former times there were many mysterious events happening around them, which they transmitted through this genre. Today, such events happen no more (UIHLL 2019, AR 216, №30).

\section{THE SYSTEM OF RITUAL SONG GENRES}

Relying on field material and on written sources, we have attempted to distinguish the main genres of ritual song recorded in the diaspora group of Chainsk district Udmurt, and to connect them to their original musical tradition (Table 4). The use of ritual singing folklore shows its resilience to external influence, unlike the non-ritual layer. For comfort, we shall denote these traditions with the terms 'Chainsk tradition' (the Siberian migrant tradition) and 'Sharkan tradition' (the Udmurt original). 
Table 4. The genre system of the ritual songs in the Chainsk and Sharkan traditions.

\begin{tabular}{|c|c|c|}
\hline \multicolumn{3}{|c|}{ Ritual songs } \\
\hline & $\begin{array}{l}\text { Chainsk tradition } \\
(1974,2001,2003,2006) \\
\text { With the quantity of samples we } \\
\text { know of }\end{array}$ & $\begin{array}{l}\text { Sharkan tradition } \\
(1995,2001,2019)\end{array}$ \\
\hline $\begin{array}{l}\text { Songs from } \\
\text { calendar } \\
\text { rituals }\end{array}$ & & $\begin{array}{l}\text { - turnan dyr"ya kyrdzh'an - } \\
\text { Haymaking songs } \\
\text { - dancing/round dance songs }\end{array}$ \\
\hline $\begin{array}{l}\text { Songs from } \\
\text { clan/family } \\
\text { rituals }\end{array}$ & $\begin{array}{l}\text { Wedding songs: } \\
\text { - s'yuan gur (3) - } \\
\text { Wedding song, performed by the } \\
\text { kin of the bridegroom, in the bride's } \\
\text { home; } \\
\text { - s'yuan kyrdzh'an (4) - } \\
\text { Wedding song, performed by the kin } \\
\text { of the bride while accompanying the } \\
\text { bride out of her parents' home } \\
\text { Recruiting songs: } \\
\text { - soldat kelyan gur (1) - } \\
\text { Song performed while accompanying } \\
\text { recruitment into the army; } \\
\text { - nekrut kelyan kyrdzh'an (1) - } \\
\text { Performed while accompanying } \\
\text { recruitment into the army; } \\
\text { Guest songs: } \\
\text { - table songs (3) }\end{array}$ & $\begin{array}{l}\text { Wedding songs: } \\
\text { - s'yuan gur/golos/kyrdzh'an- } \\
\text { Wedding song, performed by the kin of } \\
\text { the bridegroom, in the bride's home; } \\
\text { - kelis' gur - } \\
\text { Wedding song, performed by the kin of } \\
\text { the bride while accompanying the bride } \\
\text { out of her parents' home } \\
\text { Recruiting songs: } \\
\text { - nekrut gur/golos/kyrdzh'an - } \\
\text { Song performed while accompanying } \\
\text { recruitment into the army; } \\
\text { - tuk shuhkkon gur - } \\
\text { Song of the nailing of the tuk; } \\
\text { - nekrut kelyan/armiye kelyan kyrdzh'an- } \\
\text { Performed while accompanying } \\
\text { recruitment into the army; } \\
\text { Guest songs: } \\
\text { - kuno pumitab gur/kyrdzh'an - } \\
\text { Song for receiving } \\
\text { guests; } \\
\text { - kuno utyalton/dzhöks'ör kyrdzh'an- } \\
\text { Song for servings spirits to guests } \\
\text { - korka pyron dyr"ya kyrdzh'an - Song } \\
\text { performed when somebody settled in a } \\
\text { new home } \\
\text { Funeral and commemorative songs: } \\
\text { - grob duryn kyrdzh'an - } \\
\text { Song performed beside the coffin; } \\
\text { - kulem murtez kelyan gur/kyrdzh'an- } \\
\text { Song performed while accompanying } \\
\text { the dead. }\end{array}$ \\
\hline
\end{tabular}

As Table 4 shows, two terms denote the songs in both traditions - gur ('melody', 'tune') and kyrdzh'an ('song'). The first - gur - characterised the definition of the ritual genres. It is widely spread in southern Udmurtia. In addition to these, in the Sharkan tradition there is another term to denote ritual songs, the word golos, adapted from Russian, which is also used in northern Udmurtia. The term kyrdzh'an comes from the verb 'to sing' and denotes the belonging of a song to the non-ritual category. These are songs with traditional lyrics, of late origin, author songs and loan songs. Nevertheless, in both 
traditions this term is also used for ritual songs of late origin. Thus, the terminological investigation shows the intermediate position of the Sharkan tradition, in which southern and northern Udmurt phenomena are combined.

In the singing tradition of the Chainsk Udmurt, there are no examples of calendar songs. In the Sharkan tradition, however, there are examples, although they are also rare, for example haymaking songs, i.e. non-ritual, lyrical, author songs ("I Got up Early in the Morning and...", "Incredibly Enjoyable Spring Night..."), and round dance songs that are in Russian or translated into Udmurt ("The Maid Reaped the High Rye...", "Alexandrov's Birch...", "Two Birds Flew...", “Our Marusya Sowed Wheat...", "Have a Look at My Garden..."). This last was performed during spring and summer. The clan and family songs, unlike the calendar ones, have endured better in both traditions: these are wedding, recruiting, and guest songs. In the Chainsk tradition, there are some samples of wedding and recruiting songs, while the guest songs are represented by only one example, the table song "Let Us Drink, Let Us Drink This Wine...". This song, according its musical characteristics, is from a late layer and is not typical to this tradition. In the Sharkan musical folklore there is, among the clan and family songs, a cycle dedicated to funeral and commemorative rites that has not been recorded among the Chainsk Udmurt.

\section{WEDDING SONGS}

There are two types of wedding song, wedding songs performed by the bridegroom's kin in the bride's house, and accompanying/wedding songs performed by the bride's kin while accompanying the bride from her native home. There are three samples of the first type - s'yuan gur - recorded in Chainsk district, Tomsk oblast that are variants of one type of song represented in the Sharkan tradition. The contents of the poetic text describes the procession to the home of the bride. The most archaic motifs are those that describe the short trip and how animals and birds are met along the way. This motif contains ancient mythological content, the members of the procession being seen as representatives of the world beyond (Vladykina 1997: 114).

Мьниӥм ик, мьнӥм ик, иур дуртӥз ик,

Докъяез ик «кот-кот» карьлӥз.

Мьнӥм ик, мьниӥм ик бадь ултӥз ик,

Сялаез ик «чик-чик» карьлӥз.

Мьнӥм ик, мынӥм ик сик ултӥз ик,

Коньвез ик «тюр-тюр» карьиӥз.
We have come, we have come along the river, along the cliff,

[Where] all the way the grouse sings. We have come, we have come under the willows,

[Where] all the way the grouse whistled. We have come, we have come through the woods, through the woods

[Where] all the way the squirrel twittered.

(UIHLL 1974, TR 34-2, №4. Translated by the authors.)

In the Sharkan samples we find another version of the text. In the same way, the route of the procession goes through woods where participants hear birdsong. In addition, they cross a 'culture' landscape connected to man's work (field, pasture). We see this theme as a later version of the procession completed using agricultural metaphors. 
Льктӥм ик, льктӥм ик сяськаясь возьёс кузя,

Турнасьёслэн(

жин(ь) » гинэ но каризы.

Льктӥм ик, льктӥм ик ӥужектӥсь но ӟег uор (bi)mü,

Арасьёслэн(ь) сюорлоёссь «реж-куаж» гинэ но каризь.

Льєктӥм ик, Аькктӥм ик вож-вож нюләсъёс $n$ sop $(b i) m \ddot{u}$,

Тьлобур (bl)до «чир $(b l)-ч и р(b l) » \kappa ь р(b l) \ddot{a} а з$, «чир $($ bl)-чир $($ bl $)$ гинэ но чузъяськиз.
We have come, we have come through blooming fields,

The reaper's scythe just rang clearly "zhinzhin", just rang.

We have come, we have come through the blooming rye,

The reapers' sickle rang clearly "rezh-kuazh", just rang.

We have come, we have come through the green wood,

The birds sang clearly, "chir-chir", their voices rang clearly.

(UIHLL 1995, AC 145/1-2, №2. Translated by the authors.)

Another part of the wedding song's s'yuan text tells about the arrival of the procession at the bride's home (both in the Chainsk and Sharkan samples). These are the most stable motifs in the tradition, expressing the contrast between 'our own' and 'the others'. In Udmurt's traditional culture, the home and the hearth appear as "a concentrated expression of the humanised space, which acquired the highest sacral significance" (Vladykin 1994: 218). Thence the importance of the house's boundaries, so that all that is out of one's own space, the native space, was perceived as alien and hostile. It is therefore not surprising that in the lyrics of wedding songs, attention focuses on the crossing of borders, on the threshold, for example gates and doors, mirroring the wedding ritual and the procession from the bridegroom's side. The alien dimension of the newcomers appears in the extraordinary way that doors are opened using a copper, silver or gold lever, a point that emphasises the destructive function of the newcomers.

Ысватмицлэн ӟесь дораз ук вуим но, ьиргон зырьин бералтыса пьримы.

Корказ ик(ь) пьиим но, куинь котьр ик котьркким.

Аькктӥм ик, лькктӥм ик Балтач но(й) ульча кузя.

Иван( ьь) сватләсь дьворзә, дьиворзә азвесь зырынн(ьь) бералтом.

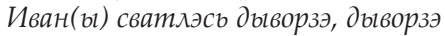

зарни зырын(

Пьирим ик, пьрих ик Иван сватлэн азбараз.

Ысватмицлэь ӧсъёссэ но азвесь зырыни(ь) берал(

Ысватмиллэв ӧсъёссэ но зарни

зырыни(ь) берал(ъl)том.
We have come to the gate of our in-laws, opening it with a copper lever, we have entered.

We have entered the house, yes, and thrice circled around it.

(UIHLL 1974, TR 33-2, №5. Translated by the authors.)

We have come, we have come through

Baltach street,

The yard of our in-law Ivan, we open it with a silver lever.

The yard of our in-law Ivan, we open it with a gold lever.

We have entered, we have entered the yard of our in-law Ivan.

The doors [of the house of] our in-law we open them with a silver lever.

The doors [of the house of] our in-law we open them with a gold lever.

(UIHLL 1995, AC 145/1-2, №3. Translated by the authors.) 
All the actions accomplished by the participants of the wedding procession are meant to call for a response from the other side, for example tears from the bride and her mother, as appears in texts from both traditions.

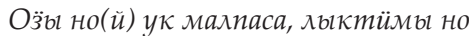
ми ук, эщ,

Молдушкамыләсь сюлэмзэ но вырӥъттьн.

Эмеспимез шумиоттытом, молдушкамез бӧрӥьтом.

Ой-дой шуса но малпаса лыктӥм ук.

Мынӥм ик, мынӥм ик сик ултӥно бадь ултий.

Ой, дӥ, дунӥ, дунӥ, дой гинэ но.

Молдушкамез вырӟьттом, ысватьямес бӧрӥьтом.

Ой, дӥ, дунӥ, дунӥ, дой гинэ но.
Thus reflecting, we arrived, we arrived, friends,

To trouble the heart of the bride.

We rejoice our bridegroom, we drive the bride to tears.

Oy-doy, talking and reflecting, yes, we arrived.

(UIHLL 1974, TR 33-2, №5. Translated by the authors.)

We went, we went through the wood, through the willow wood.

Oy, di, duni, duni, doy, yes only yes.

Our young bride, we trouble her, our in-law, we make her weep.

Oy, di, duni, duni, doy, yes only yes.

(UIHLL 1995, AC 145/3-1, №13. Translated by the authors.)

Before leaving the bride's home, members of the procession perform another text using the same song, the topic of which is abandoning one's native space. The song enumerates the markers of the native environment, for example parents and friends, and mentions how the bride worked in her parents' house.

Аьӧль-льӧль ик(ь) ӝсущ̈салоз бакча шорад мак сяська.

Соку тодад льктоз мамиедләсь вордэмзэ.

Соку тодад льктылоз ик мамиедлэсь вордэмзэ.

Юг-юг ик(ь) ґ̈суӝсалоз бакча шорам мак сяська.

Соку тодад льктоз ук тятиедлэсь вордэмзэ.

Соку тодад льктылиоз ик тятиедлэсь вордэмзэ.

Ӵуж-ӥуж ик(ь) ӝсую̈салоз воз вылад ук итамас. Соку тодад лькктоз урчче шудэм эиъёстэ.

Соку тодад льктылиоз ик урчче шудэм эшъёстэ.
Crimson-crimson rises the poppy flower in the middle of the garden.

Then you remember how your mother brought you up.

Then you remember how your mother brought you up.

White-white rises the poppy in the middle of the garden.

Then you remember how your father brought you up.

Then you remember how your father brought you up.

Yellow-yellow rises the buttercup in the field Then you remember the friends with whom you played.

Then you remember the friends with whom you played.

(UIHLL 1974, TR 33-2, №6. Translated by the authors.) 
The house is a form of protection from the external misfortunes of life. Therefore, the topic of abandoning the parental home is deeply emotional, especially when comparing one's space with an alien space. This example comes from the Sharkan tradition.

\author{
Ӵьж-ӥьж гинэ ӝсужалоз бакчаяд но \\ мак сяська. \\ Соку тодад льктылоз шудьны но \\ nотамдэ. \\ Only yellow-yellow rises the poppy in \\ the garden. \\ Then you remember how you went out to \\ play. \\ Ӵуж-ӥуж гинэ ӝсужалоз бакча берын \\ Only yellow-yellow rises the buttercup \\ италиас. \\ Соку тодад лыкктылоз турнаны но \\ потондэ. \\ behind the garden. \\ Then you remember, \\ how you went out to make hay. \\ Аьъз-льцз гинэ ӝсужалоз сюрес дуре \\ льзсяська. \\ Соку тодад лыктылоз араны но потондэ. \\ Only blue-blue rises the cornflower by the \\ road. \\ Then you remember how you went out \\ harvesting. \\ Аслад гидкуаед уз лу, мурттлэн \\ коргидъёсыз адскозыл. \\ It will not be your yard, unfamiliar \\ barns will be before your eyes. \\ Ой, дӥ, Әунӥ, дунӥ, дой гинэно. \\ Oy, oy, di, duni, duni, doy only yes. \\ Ӵукна вазь ик султӥд ке, ву дуре \\ When you get up early in the \\ мынӥд ке, \\ Музон пролкае, ой, эн мын, астэ \\ воӟытэ уськытод. \\ Ой, дӥ, дунӥ, дунӥ, дой гинэ но. \\ morning, you go to the water, \\ Do not turn in an unfamiliar lane, oh, \\ don't, people will laugh. \\ Oy, di, duni, duni, doy only yes.
}

(UIHLL 2019, AR 216, №51. Translated by the authors.)

In the last fieldwork recordings made in Sharkan district, in 2001 and 2019, this tune is often performed with a text typical of non-ritual lyrical songs. Here, the main emphasis is on emotion, on the sufferings of the lyrical hero, and on the topic of an unhappy fate.

Тӧдьь кьччу вож куаро но, маль медам гуриё?

Пинал йыры туж пинал, маль медам кайгуо?

Пинал йыры туж пинал, маль медам кайzуо?

Пинал йьюры, вож муугор (ь) ветлэ секьтт азьёстӥ.

Пинал йьıры, вож м⿻угор (ol) ветлэ секьт азьёстӥ.

Узы меда, борь меда, кудзи азьлон кисьмало?

Анай меда, атай меда, кудзы шудтэм вордӥллям?
The white birch has green leaves, but why is it bearing earrings?

My young head is very young, but why is it unhappy?

My young head is very young, but why is it unhappy?

My young head, my young body roams in unfamiliar places.

My young head, my young body roams in unfamiliar places.

Strawberries, wild strawberries, which [of them] will ripen sooner?

A mother, a father, which [of them] brought up an unfortunate?

(UIHLL 2001, AC 166/1-1, №11. Translated by the authors.)

Below, we shall present a musical analysis of the wedding songs recorded in the Chainsk and Sharkan musical folklore traditions. In both traditions, the structure of the lyrics to 
the wedding song consists of two or three lines with a caesura, followed by a refrain $(\mathrm{AR}, \mathrm{ABR})$ (Figures 3 and 5), or also without (AA, AB, ABB) (Figures 4 and 6). The refrain consists of an accumulation of refrain words to which the singer may add some meaningful text. This phenomenon brings the Sharkan tradition closer to the northern Udmurt singing tradition. In each line, the quantity of syllables varies from 10 to 21 .
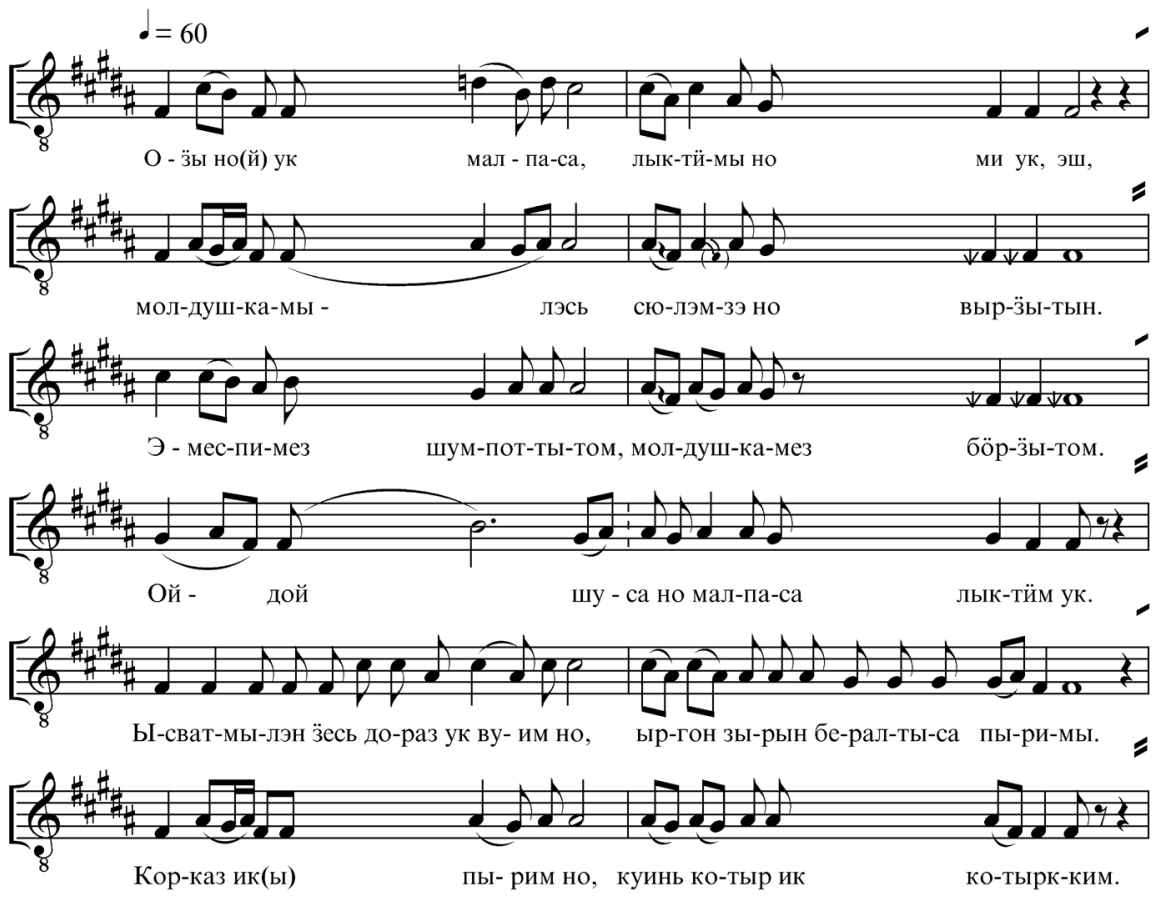

Figure 3. S'yuan gur, wedding song (UIHLL 1974, TR 33-2, №5).

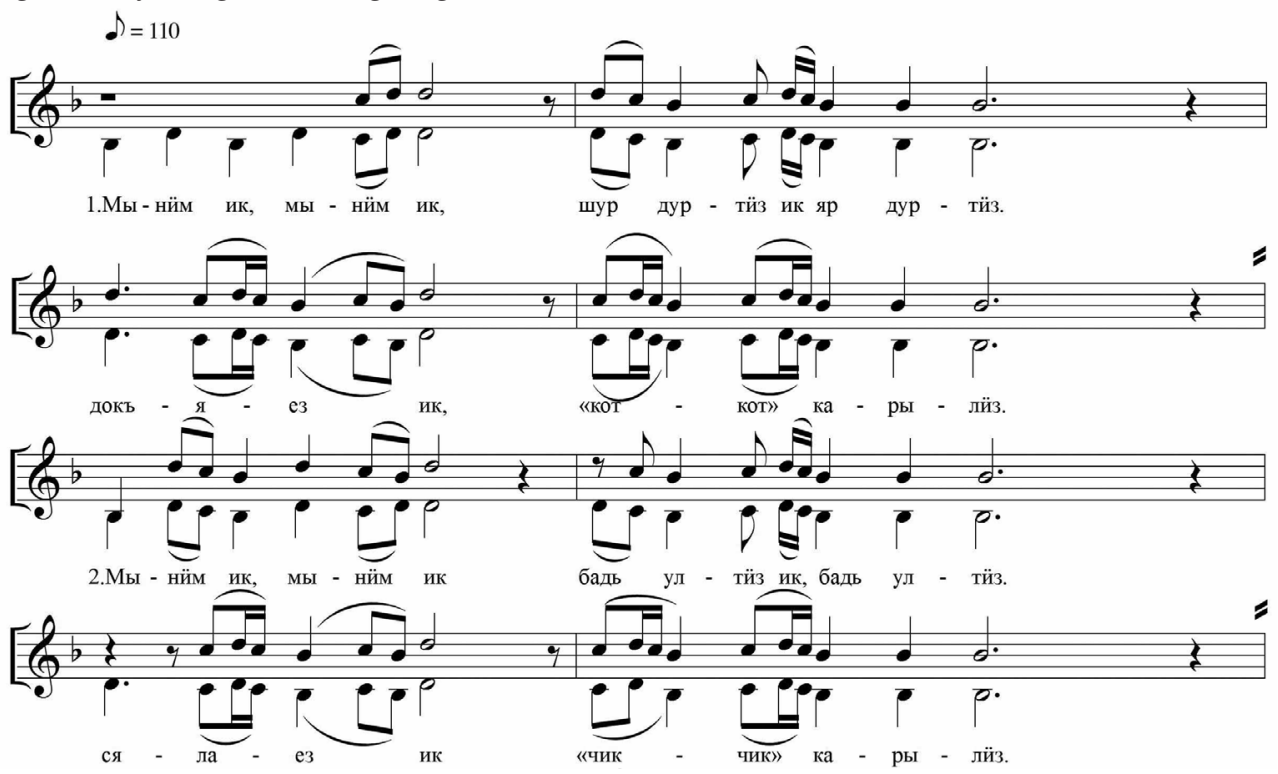

Figure 4. S'yuan gur, wedding song (UIHLL 1974, TR 34-2, №4). 

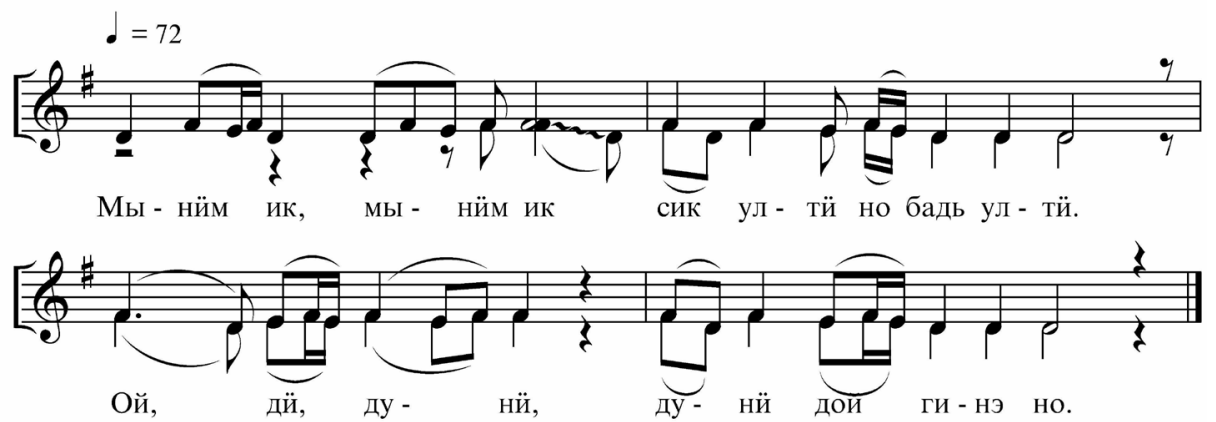

Figure 5. S'yuan gur, wedding song (UIHLL 1995, AC 145/3-1, №13).

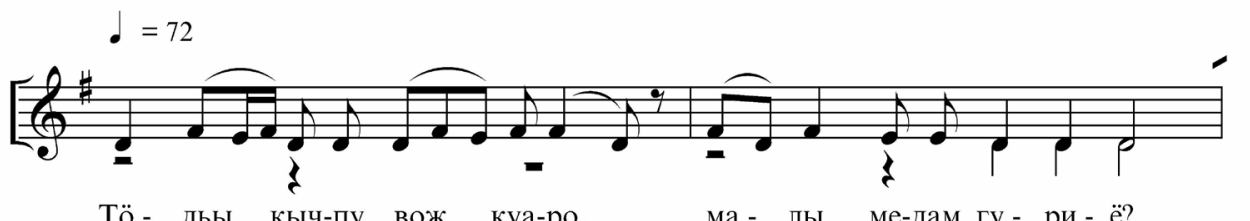

Тӧ - дьы кыч-пу вож куа-ро, ма - лы ме-дам гу - ри - ё?

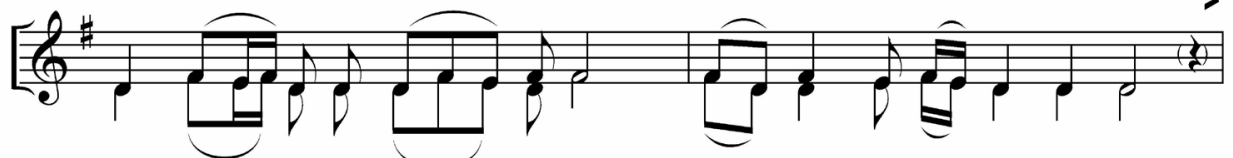

Пи - нал йы-ры туж пи-нал, ма - лы ме-дам кай -гу - о?

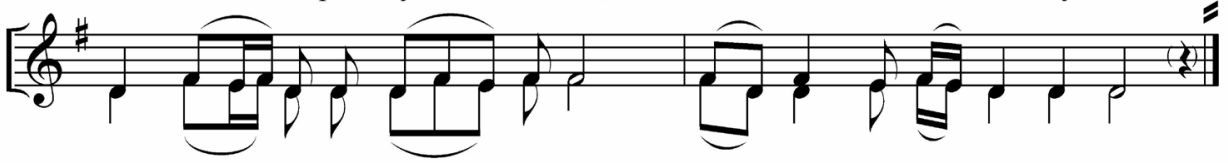

Пи - нал йы-ры туж пи-нал, ма - лы ме-дам кай - гу - о?

Figure 6. S’yuan golos, wedding song (UIHLL 2001, AC 166/1-1, №11).

The rhythmic organisation of the stanzas relies on two periods. The second part of each period has a similar structure, with smaller variations: - abcb $b_{1}$ There are two main

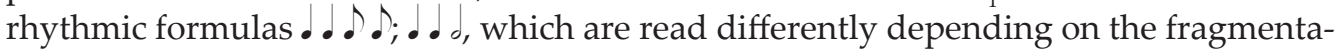
tion or the extension of the durations. This has consequences on the number of syllables

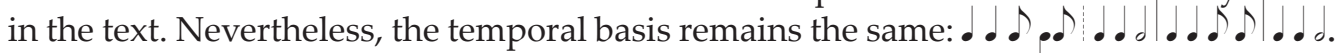

We have an example of rhythmic variation in one Chainsk sample (Figure 3). In the third and fourth stanzas, the rhythmic contour of the period is expanded with additional rhythmic formulas: ..D. .). .):

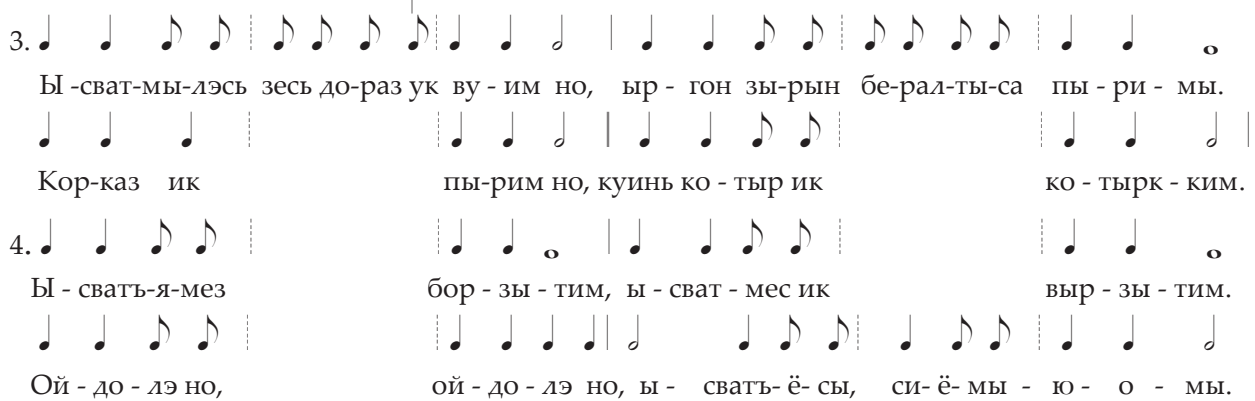


We argue that these variations may have different causes: the distance from the original tradition and the peculiarities of a single performer, as this version has been recorded only by one performer - Anna Vladimirovna Vladykina (born 1914). The scale in the wedding songs in the original tradition relies on a major trichord - c-d-e (Figures 5-6), extending in some samples to a tetrachord bounded by the interval of a fifth - c-d-e-g. The Chainsk tradition also includes the major trichord (Figure 4). However, the other two examples among the samples presented above differ from those previously commented on because of the diatonic scale bounded by the interval of a fifth - c-d-e-f-g (Figure 3). This depends on the melodic development because the opening phrase of the song in the last examples is characterised by a leap of a fifth from the lower tone, and its vocal reperformance (c-g) incorporates a sixth tone. At the same time, the Sharkan examples are characterised by an ascending leap from the key note by a third (c-e).

The melodic stanza also consists of two or three musical periods of repetitive nature with small varietal deviations - A(ab) $\mathrm{A}_{1}\left(\mathrm{ab} ; \mathrm{a}_{1} \mathrm{~b}_{1} ; \mathrm{cb}_{1}\right) \mathrm{A}_{1}\left(\mathrm{ab} ; \mathrm{a}_{1} \mathrm{~b}_{1} ; \mathrm{cb}_{1}\right)$.

The Sharkan Udmurt call the second type of wedding song kelis' gur, the Chainsk s'yuan kyrdzh'an. The difference appears not only at terminological level, but also in the poetic texts. Thus, in the Sharkan versions, we find the traditional motif of separation from the native home and parents:

Кьлёд ук, кьиёд ук тон, апие,

Ми гуртамы бертомы.

Гуртамы бертӥм ке, ӧсӧк сьӧрамы пуксёмы,

Одӥг тон гинә уд нӥ у․

Огмы шоры огмы учком но,

Одӥг тон гинә уд нӥ ху.

\section{Ӵукаӟяз ӥукна сул(ъ)тыса,}

Азбаре но потылод.

Азбарад но потылӥ̈ ке,

Аслад азбаред уз нӥ лу.

Азбаре но потылий ке,

Аслад азбаред уз нӥ лу.
You are remaining, you are remaining, my sister, We return home.

We return home, sit around the table, But only you will not be with us.

We shall look to one another, yes, Only you will not be with us.

Tomorrow morning you will wake up,

You will go out into the yard.

You will go out into the yard,

But you shall not see your yard.

You will go out into the yard,

But you shall not see your yard.

(UIHLL 1995, AC 145/1-2, №5. Translated by the authors.)

In the text of the wedding farewell/accompanying song in the Chainsk tradition the first motif is about the marriage of an Udmurt girl against her will, something that was not recorded in the original tradition. The metaphors of this text (the Udmurt girl, the nightingale, youth), and the technique of psychologic parallelism, built on the description of the girl's state of mind, counterbalancing environing nature's harmony, her direct address to her mother, reveal that this genre belongs to non-ritual singing. 
Огназ пуке малпаськыса,

Укно ульнн удмурт ныл.

Уӥь чебер кьтрӥаса улэ

Вадьсаз кьӥпу йьльюн.

Уӥь чебер кырйаса улэ

Ватьсаз кьӥпу йьлььн.

Уӥы туж чебер кырӟа,

Куараез кыдёке шуккиське.

Удмурт ныллән сюләм бӧрдэ,

Бам йыльёсаз синву адске.

Удмурт нылхән сюлэм бӧрдэ,

Бам йыльёсаз синву адске.

Сое туннэ кузпалиы сёто,

Чик асләсьтыз юатэк.

Егит даурзэ быдто,

Чик иул(ъ)дырен(ъ) ультэк.

Егит даурзэ бъцто,

Чик иул(ъ)дырен улытэк.

Вордэм мусо мемие,

Яратоно муртлы сёты вал.

Сокем сюлми (x)ӧй бӧрдысал,

(Х) Ӧй потысал синвуосьь.

Сокем сюлии (x)ӧй бӧрдысал,

(Х)Ӧй потысал синвуосьь.
She sits alone, in her thoughts,

Under the window, the Udmurt girl.

The nightingale sings beautifully

Nearby, on the top of a birch.

The nightingale sings beautifully

Nearby, on the top of a birch.

The nightingale sings most beautifully,

His voice carries far.

The Udmurt girl's heart weeps,

Tears run along her cheeks.

The Udmurt girl's heart weeps,

Tears run along her cheeks.

She is given today in marriage

Against her will.

They kill her youth,

In life, it will not see joy.

They kill her youth,

In life, it will not see joy.

Oh, my dear mother,

If only you had given me to a loved one.

Then my heart would not weep thus,

My tears would not fall thus

Then my heart would not weep thus,

My tears would not fall thus.

(UIHLL 1974, TR 34-1, №14. Translated by the authors.)

The poetic stanza consists in two or three lines of 15 or 16 syllables, with repetition of the second line $(\mathrm{AB}, \mathrm{ABB})$. Because of fragmentation, the number of syllables in the line may reach 21, although the duration does not change.

The rhythmic organisation of the line has a similar structure - a repeated isochronic line of eight units where the duration of the last syllable can increase, thus making a line equal to as many as ten relative units:

The musical stanza follows the repetitions $\mathrm{A}(\mathrm{aa}) \mathrm{B}(\mathrm{bc}) \mathrm{B}(\mathrm{bc})$. The melodic and intonational development is wave-like. The first line (period) relies on the upper pentachord, C-d-e-fis-g, and is supported by the performance of the upper key note, while the second half of the song sounds in the lower part of the scale, G-a-h- $\mathrm{c}^{1}-\mathrm{d}^{1}-\mathrm{e}^{1}$, as a result of the descending movement from the upper key note to the lower one. Thus, the scale of the song develops within the range of one octave (Figures 7-9). 


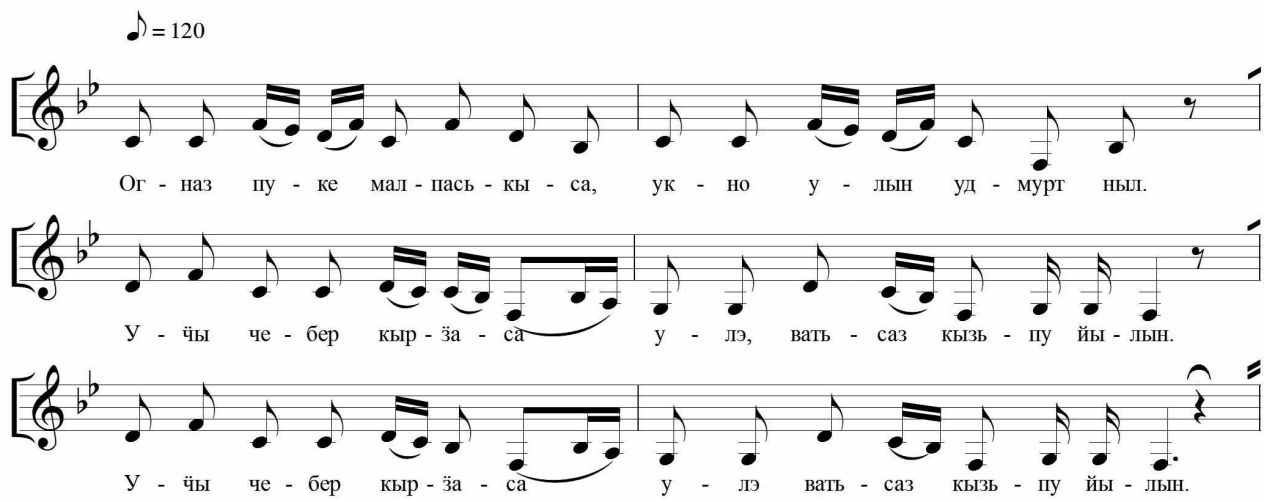

Figure 7. S'yuan kyrdzh'an, wedding song (UIHLL 1974, TR 34-1, №14).
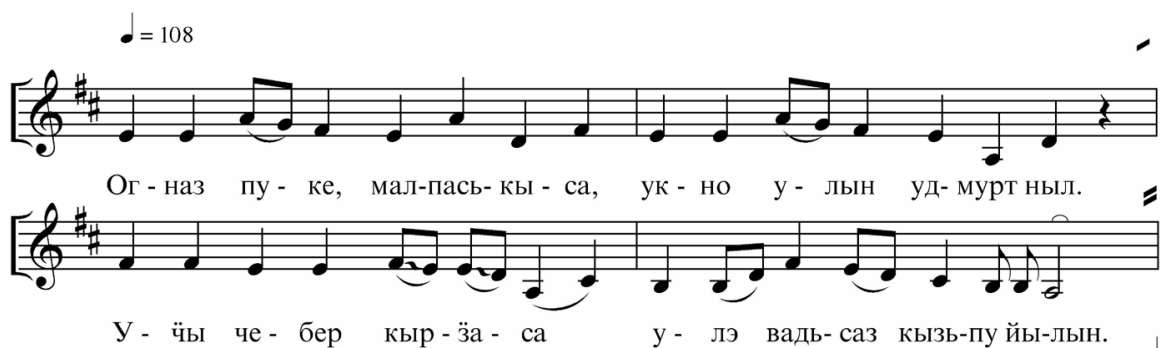

Figure 8. S'yuan kyrdzh'an, wedding song (UIHLL 2006, AC 198/2-2, №7).

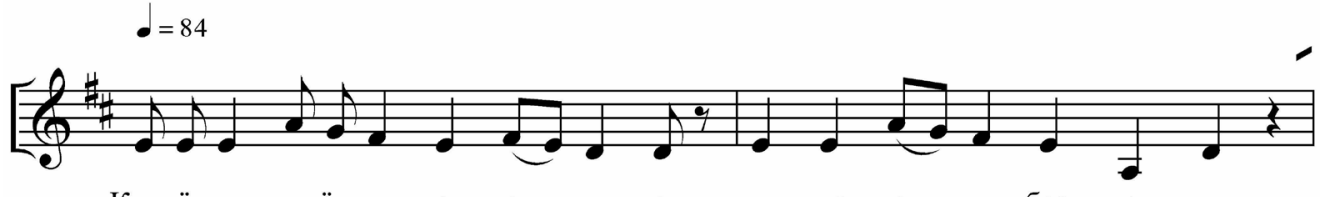

Кы-лёд ук, кы-лёд ук тон, а - пи - е, ми гур - та - мы бер - то - мы.

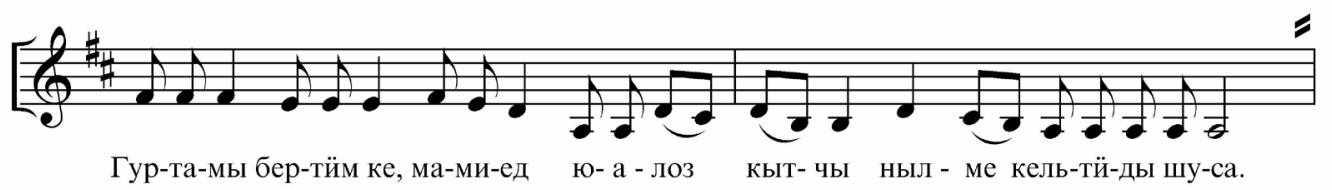

Figure 9. S’yuan kyrdzh'an, wedding song (UIHLL 2019, AR 216, №52).

\section{RECRUITING SONGS}

Within the ritual of recruiting to the army there are two types of song, nekrut gur/golos/ kyrdzh'an - and nekrut kelyan/armiye kelyan kyrdzh'an. The first has not been recorded in the singing tradition of the Chainsk Udmurt, and therefore we concentrate on the second type.

The 1974 fieldwork recorded two samples of this type. One of them - soldat kelyan gur - was recorded from a woman born in the Debësy district of the UR, and differs 
from the recruiting songs of the Sharkan tradition. The other - nekrut kelyan kyrdzh'an belongs to the second type of conscript songs in the original musical folklore. We also recorded one version of this song in Karsashur, Sharkan district UR, in 2019. We shall now analyse both versions in detail (Figures 10 and 11).

The motifs reflect typical topics of recruiting songs, i.e. the imposed need to replace customary economic activity within a familiar space with a warlike activity in an unfamiliar environment.

Геры но кутон киёсы вал но,

Пиӥал но кутьнн кьлицзы.

Борозда лёган пьдъёсы вал но,

Куӟ сюрес лёган кылизы.

Борозда лёгон пьдъёсь вал,

Куӟ сюрес лёгон каризы.

Геры кутон но(й) киёсы вал,

Пийал кутон но(й) каризь.

Сюрло нуллон но(й) пельпульв вал,

Котомка нуллон(ъ) каризы.
My hands were made to hold the plough, I had to hold a rifle.

My legs were made to walk the furrow, I had to walk on a long road.

(UIHLL 1974, TR 33-2, № 2. Translated by the authors.)

My legs were made [to] walk the furrow I had to walk on a long road.

My hands were made [to] hold the plough, I had to hold a rifle.

My shoulders were made [to] carry a sickle, I had to carry a knapsack.

(UIHLL 2019, AR 216, №55. Translated by the authors.)

In addition, in the Chainsk version, the emotional aspect of the poetic text is more intense and expresses the dire state of the person's feelings. We argue that this reflects a state of nostalgia towards the conscript's 'small country', having suffered the hard migration to Siberia:

Э, тӥнь та сюрес, миар сюрес та кузя,

Некьтынин но пумизз ӧвӧл.

Э, та куректон, мар куректон тайе,

Неку но пумьзз но ӧвӧл.

Э, та куректон, мар куректон таӥе,

Неку но пумьзз но ӧвӧл.

Э, тӥнь та тӧл, ма тӧл таӥе тӧлаське,

Бадьпу ньӧртёсть ик сэзъя.

Э, та куректон, мар куректон та,

Тӧльин но уг ик тӧлатъя.

Э, та куректон, ма куректон та,

Тӧльнн но уг ик тӧлатья.

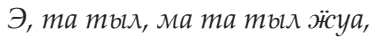

Вуэн кичкатэк уг кысыл.

Э, та куректон, ма та куректон таӥе,

Вуэн кичкаса но уг кьс.

Э, та куректон, мар та куректон таӥе,

Вуэн кичкаса но уг кьс.
Oh, this road, what a long road

Nowhere is it at an end.

Oh, this suffering, what suffering,

Never is it at an end.

Oh, this suffering, what suffering,

Never is it at an end.

Oh, this wind, why does it blow so strongly,

The willow's branches rock.

Oh, this suffering, what suffering,

Even in the wind it finds no relief.

Oh, this suffering, what suffering,

Even in the wind it finds no relief.

Oh, this fire, why does it burn so, why

does it burn so,

Even the water does not put it out

Oh, this suffering, what suffering,

Even with water you do not put it out

Oh, this suffering, what suffering,

Even with water you do not put it out ${ }^{6}$

(Atamanov 2004: 94).

The poetic stanza has a form in two or three parts $(A B, A B B, A B C)$, and at the same time the song covers a line and period. 
The two examples of farewell/accompanying songs to the recruit are versions of the Russian romance's song "The Reed Buzzed, the Trees Bent...". The Udmurt version keeps the metric threeparty and general melodic contour: an ascending leap from the key note in the first half of the stanza, and the downward gradual descent from the basic tone in the second.

The scale relies on the diatonic structure of Udmurt songs, but differs in volume: in the Chainsk version the scale of the song develops within the range of an octave (f-g$\left.a-B-c^{1}-d^{1}-e s^{1}-f^{1}-g^{1}-a^{1}-b^{1}\right)$, while the Sharkan version has a six strings mood (Fis-gis-a-hcis $\left.{ }^{1}-d^{1}\right)$. When making a comparison it is easy to guess a two-voice melody in third, in which the Chainsk version performs the higher voice (Figure 10), and the Sharkan, the lower (Figure 11).

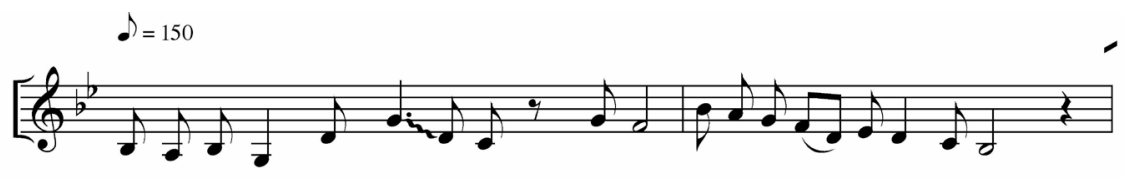

Ге-ры но ку - тон ки - ё-сы вал но, пи-ӥал но ку-тон кы-ли-зы.

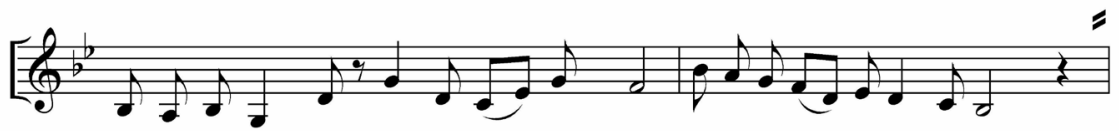

Бо-роз-да лё - ган пыдъ-ё - сы вал но, куӟ сю-рес лё-ган кы- ли-зы.

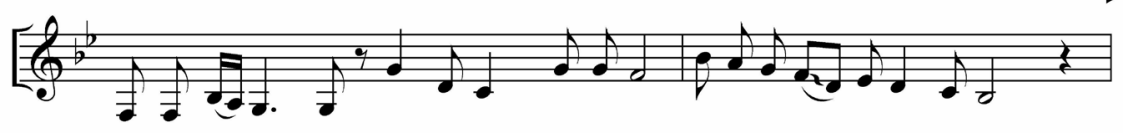

Э, тӥнь та сю - рес, мар сю-рес та ку-зя, не-кы-тын но пу-мыз ӧ-вӧл.

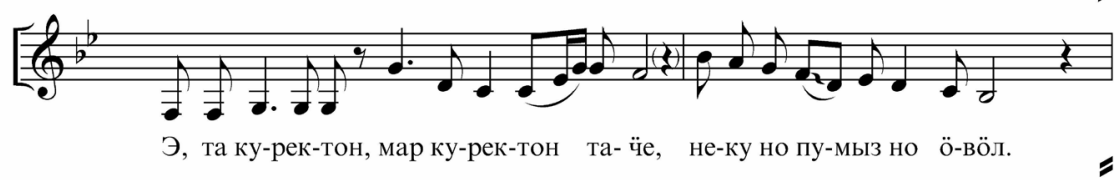

Figure 10. Nekrut kelyan, farewell/accompanying song for the recruit (UIHLL 1974, TR 33-2, №2).

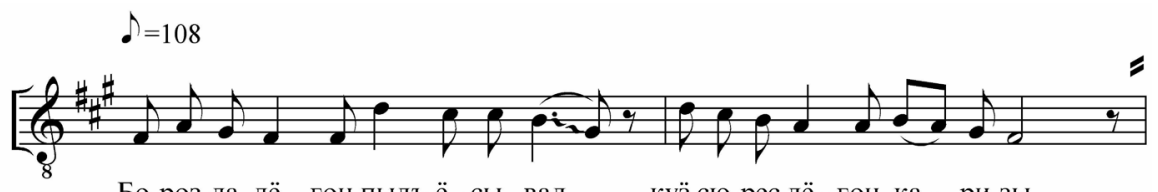

Бо-роз-да лё - гон пыдь-ё - сы вал, куӟ сю-рес лё - гон ка - ри-зы.

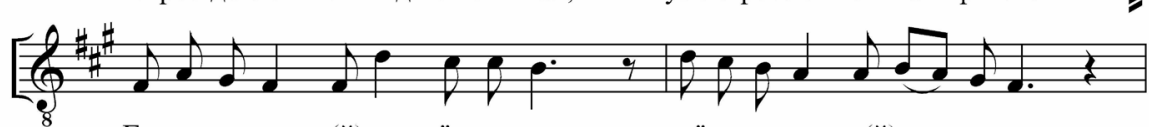

Ге- ры ку-тон но(й) ки - ё - сы вал, пи-ӥал ку-тон но(й) ка - ри-зы.

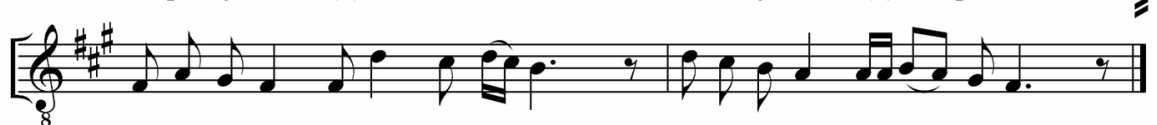

Сюр-ло нул-лон но(й) пель-пу-мы вал, ко-том-ка ну-лон-н(ы) ка-ри-зы.

Figure 11. Nekrut kelyan kyrdzh'an, farewell/accompanying song for the recruit (UIHLL 2019, AR 216, №55). 
The two examples of farewell songs differ in the stability and the variation of some structures, such as the number of syllables per line and the rhythmic scheme. The first characterises the original tradition, where we notice the permanence of these two indicators: the quantity of syllables is 17 and the base for the rhythmic line/period is

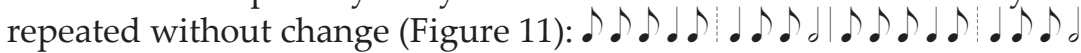

The Chainsk song sample is characterised by variation in the number of syllables per line (from 16 up to 20) and by the diversity of the versions of the first half of the rhythmic period, while the second remains stable (Figure 10):

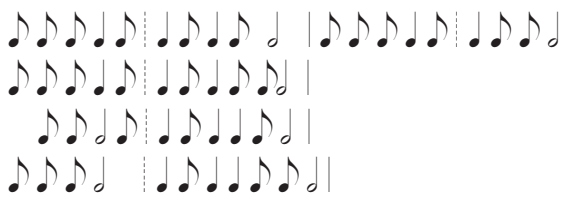

The diversity of the rhythmic formulas provokes the multitude of melodic variations.

\section{CONCLUSION}

To sum up our comments above, we argue that both traditions maintain the typical features of the wedding and recruiting songs that exist in the original musical folklore of the Sharkan region. The first type of wedding song, syuan gur/golos/kyrdzh'an (wedding songs performed by the bridegroom's kin in the house of the bride) belongs to an archaic layer, while the second, kelis' gur/s'yuan kyrdzh'an (farewell/accompanying song at the wedding), as well as the farewell song to the recruit, nekrut kelyan kyrdzh'an, have a later origin. The rhythmic structure of the wedding songs is stable, while melodic and intonational peculiarities may vary. Among the two types of wedding song, the one characterised by melodic variation belongs to the Chainsk tradition, while the Sharkan samples are relatively stable. We can say the same about the recruiting songs, in which we observe some improvisational rhythm and melody in the Chainsk versions, as well as stability of the Sharkan sample.

Some differences in the content of the poetic texts have also been highlighted. Thus, the text from the Chainsk s'yuan gur contains more ancient metaphors connected with nature and non-domesticated locations in the landscape. In the kelis' gur/s'yuan kyrdzh'an the emphasis changes: in the Sharkan versions we find the motif of separation from the native space, the home, the parents, while in the Chainsk version what is highlighted is marriage against the bride's will. In the recruiting songs of the Chainsk tradition, the emotional dimension is emphasised, which seems to be directly in connection with the Siberian Udmurt nostalgia for their 'small country'. We argue that the mobility of the metaphors in the Chainsk versions may be due to the distance from the original tradition, which allows on the one hand some freedom with the frames and on the other underlines the emotionality of reception. All this together allows some kind of freedom in the performance and forms the originality of 'Siberian' musical folklore. Unfortunately, the small number of musical samples does not allow us to confirm this hypothesis. This is a first attempt to analyse two traditions, the one of the migrants and the other the original, which opens new perspectives about Udmurt musical folklore. We shall pursue this enterprise using the example of other ethnographic groups of Siberian Udmurt. 
UIHLL Ud RAS - Udmurt Institute of History, Language and Literature within the Ural Department of the Russian Academy of Sciences

UIHLL UdmFRC Ud RAS - Udmurt Institute of History, Language and Literature at the Udmurt Federal Research Centre within the Ural Department of the Russian Academy of Sciences

UR - Udmurt Republic

\section{NOTES}

1 Officially: Udmurt Institute of History, Language and Literature of the Udmurt Federal Research Centre of the Ural Department of the Russian Academy of Sciences.

2 Oral information, 2006, during a conversation between Mikhail Atamanov and Irina Pchelovodova.

3 It is possible to discover copies of the audio recordings of the UIHLL UdmFRC Ud RAS archive on the homepage of the British Library (see Vanishing Voices).

4 Oral information, 2019. Received through a conversation between Pavel Shakhov and Natal'ya Tuchkova, transmitted later to Irina Pchelovodova.

5 On the video cassette we find the rushes for a documentary film about the Udmurt living in two villages in Chainsk district, Tomsk oblast. The filmmaker is Filimonov, the author of the idea and scientific adviser is Tuchkova. The original rushes are currently in Tuchkova's personal archive with a copy in the UIHLL UdmFRC Ud RAS archive (UIHLL 2003, VR 219).

6 The delegation from Udmurtia was composed of Irina Pchelovodova, researcher at the UIHLL UdmFRC Ud RAS. Her audio recordings are kept in the UIHLL UdmFRC Ud RAS archive (UIHLL 2006, AC 198/1-3).

7 Tuk - a flap of textile that the recruit nails to a beam. Nobody touches it until he comes back, because it is the personification of the young man far away.

\section{SOURCES}

Materials of Scientific Archive UIHLL UdmFRC Ud RAS:

1974, TR 32-34. Tape recordings, tapes 32-34. Joint Fieldwork with the Udmurt State University in 1974, Chainsk district, Tomsk oblast, and Birilus, Bol'sheuluy district, Krasnoyarsk kray. Expedition leader Vladimir E. Vladykin, participants Mikhail G. Atamanov, Galina A. Korepanova (Nikitina), L. Lopatin, V. Alasheyev, A. Sminov, G. Shklyayev.

1974, TR 33-2, №2. Tape recording 33, side 2, track №2. Farewell to the conscript song (nekrut kelyan kyrzhan) sung by Anna Vladimirovna Vladykina (born 1914) in Tiga 1 (Chibysh, Chaink district, Tomsk oblast).

1974, TR 33-2, №5. Tape recording 33, side 2, track №5. Wedding song (syuan gur) sung by Anna Vladimirovna Vladykina (born 1914) in Tiga 1 (Chibysh, Chaink district, Tomsk oblast).

1974, TR 33-2, №6. Tape recording 33, side 2, track №6. Farewell wedding song of the procession members (syuanyëslen koshkon gurzy) sung by Anna Vladimirovna Vladykina (born 1914) in Tiga 1 (Chibysh, Chaink district, Tomsk oblast).

1974, TR 34-1, №14. Tape recording 34, side 1, track №14. Wedding song (syuan kyrdzhan) sung by Ida Aleksandrovna Maksimova (born 1914) in Tiga II (Shor Chainsk district, Tomsk oblast). 
1974, TR 34-2, №4. Tape recording 34, side 2, track №4. Wedding song (syuan gur), sung by Yekaterina Nikolayevna Perevozchikova (born 1912), Matrëna Dmitriyevna Stepanova (born 1905) and Dar'ya Ivanovna Kazakova (born 1906) in Tiga III (Bil'yb, Chainsk district, Tomsk oblast).

1995, AC 145/1-5. Audio cassette collection 145, cassettes 1-5. Fieldwork records of the 1995 folklore and ethnography expedition with Svetlana V. Starodubtseva, Irina V. Pletneva and Yuriy Perevozchikov in Sharkan district, UR.

1995, AC 145/1-2, №2-3. Collection 145, cassette 1, side 2, track №2-3. Wedding song (syuan gur) sung by Irina Egorovna Vesëlykh (born 1934) in Sharkan.

1995, AC 145/1-2, №5. Collection 145, cassette 1, side 2, track №5. Farewell/accompanying song by the bride's kin (kelis' gur) sung by Irina Egorovna Vesëlykh (born 1934) in Sharkan.

1995, AC 145/3-1, №13. Collection 145, cassette 3, side 1, track №13. Wedding song (syuan gur) sung by Paraskov'ya Ivanovna Gondyreva (born 1925) and Zinaida Andreyevna Vakhrusheva (born 1926) in Gondyrvay.

2001, AC 166/1-7. Audio cassette collection 166, cassettes 1-7. Fieldwork records of the 2001 folklore and ethnography expedition with Irina M. Nuriyeva and Nadezhda I. Shutova. Sharkan district, UR.

2001, AC 166/1-1, №11. Audio cassette collection 166, cassette 1, side 1, track №11. Wedding song (syuan golos) sung by Eva Konstantinovna Perevozchikova (born 1931), Anna Ivanovna Perevozchikova (born 1919) and Kapitolina Vasilyevna Perevozchikova (born 1933) in Malyy Bilib.

2003, VR 219. Video recording 219. Recorded by Andrey Filimonov and Natal'ya Tuchkova in 2003.

2006, AC 198/1-3. Audio cassette collection 198, cassettes 1-3. Fieldwork records in 2006. Recorded by Irina V. Pchelovodova. Chainsk district, Tomsk oblast.

2006, AC 198/2-2, №7. Audio cassette collection 198, cassette 2, side 2, track №7. Wedding song (syuan kyrdzhan) sung by Evgeniya Aleksandrovna Perevozchikova (born 1930) in Tiga III (Bil'yb, Chainsk district, Tomsk oblast).

2019, AR 216. Audio recording collection 216, 144 tracks. Fieldwork records recorded by Irina M. Nuriyeva and Irina V. Pchelovodova in 2019. Sharkan district, UR.

2019, AR 216, №30. Audio recording collection 216, track №30. Conversation about bailichki (beseda o bylychkakh) with Glafira Borisovna Pirozhkova (born 1951), Mayya Aleksandrovna Dobryakova (born 1939), Glafira Filippovna Anikina (born 1935) and Avgusta Yur'yevna Korepanova (born 1963) in Sil'vo.

2019, AR 216, №51. Audio recording collection 216, track №51. Wedding song (syuan kyrdzhan) sung by Nina Tikhonovna Vakhrusheva (born 1934) in Karsashur.

2019, AR 216, №52. Audio recordings collection 216, track №52. Wedding farewell song (syuan kelyan kyrdzhan) sung by Nina Tikhonovna Vakhrusheva (born 1934) in Karsashur.

2019, AR 216, №55. Audio recording collection 216, track №55. Farewell to the conscript song (nekrut kelyan kyrzhan) sung by Nina Tikhonovna Vakhrusheva (born 1934) in Karsashur.

\section{REFERENCES}

Agrarnaya reforma = Agrarnaya reforma Stol'ypina 1907-1916 gg. - kratko o sobytiyakh. - Istoriya Rossii. https://istoriarusi.ru/imper/agrarnaja-reforma-stolypina-kratko.html (accessed March 1, 2020). [Аграрная реформа Столыпина 1907-1916 гг. - кратко о событиях. - История Poсcuu. https://istoriarusi.ru/imper/agrarnaja-reforma-stolypina-kratko.html.]

Atamanov, Mikhail Gavrilovich. 1982. Obraztsy rechi sibirskikh udmurtov. - Obraztsy rechi udmurtskogo yazyka. Izhevsk: 131-153. [Атаманов, Михаил Гаврилович. 1982. Образцы речи сибирских удмуртов. - Образизы речи удмуртского языка. Ижевск: 131-153.] 
Atamanov, Mikhail Gavrilovich. 2004. Sibirskaya gruppa udmurtov. - Vordskem kyl 10: 76-95. [Атаманов, Михаил Гаврилович. 2004. Сибирская группа удмуртов. - Вордскем кыл 10: 76-95.]

Atamanov, Mikhail Gavrilovich. 2008. Sibirskaya gruppa udmurtov. - Fenomen Udmurtii 8. Udmurtskaya diaspora. Moskva-Izhevsk: Udmurtia: 186-194. [Атаманов, Михаил Гаврилович. 2008. Сибирская группа удмуртов. - Феномен Удмуртии 8. Удмуртская диаспора. МоскваИжевск: Удмуртия: 186-194.]

Dayneko, Tat'yana V. 2017. Kalendarnyye fol'klorno-etnograficheskiye traditsii belorusov Kyshtovskogo rayona Novosibirskoy oblasti. - Vestnik Kemerovskogo gosudarstvennogo universiteta kul'tury $i$ iskusstv 39: 130-136. [Дайнеко, Татьяна В. 2017. Календарные фольклорно-этнографические традиции белорусов Кыштовского района Новосибирской области. - Вестник Кемеровского государственного университета культуры и искусств 39: 130-136.]

Ismagilova, Yekaterina I. 2018. Pesennaya traditsiya chuvashey Sibiri v svete teorii intonatsionnoy kul'tury etnosa. - Vestnik Kemerovskogo gosudarstvennogo universiteta kul'tury $i$ iskusstv 45: 39-49. [Исмагилова, Екатерина И. 2018. Песенная традиция чувашей Сибири в свете теории интонационной культуры этноса. - Вестник Кемеровского государственного университета культуры и искусств 45: 39-49.]

Korepanova, Galina A. 1976. Razvitiye udmurtskoy poreformennoy derevni v kontse XIX nachale XX vv. i pereselencheskiy vopros (na primere sibirskikh udmurtov). Candidate dissertation. Izhevsk. [Корепанова, Галина А. 1976. Развитие удмуртской пореформенной деревни в конце XIX - начале XX вв. и переселенческий вопрос (на примере сибирских удмуртов). Рукопись диссертации на соискание ученой степени кандидата исторических наук. Ижевск.]

Leonova, Natal'ya V.; Galina B. Sychenko and Zhanna M. Yusha. 2015. Printsipy mnogourovnevogo opisaniya lokal'nykh pesennykh traditsiy. - Vestnik Kemerovskogo gosudarstvennogo universiteta kul'tury i iskusstv 30: 161-168. [Леонова, Наталья В.; Галина Б. Сыченко и Жанна М. Юша. 2015. Принципы многоуровневого описания докадыных песенных традиций. - Вестник Кемеровского государственного университета культуры и искусств 30: 161-168.]

Leonova, Natal'ya V. 2017. Muzykal'no-etnograficheskiye traditsii sibirskikh pereselentsev: iz istorii izucheniya Novosibirskoy konservatorii. - Vestnik muzykal'noy nauki 1 (15): 34-41. [Леонова, Наталья В. 2017. Музыкально-этнографические традиции сибирских переселенцев: из истории изучения Новосибирской консерватории. - Вестник музыкальной науки 1 (15): 34-41.]

Mymrina, Dina F. and Ol'ga A. Shitts. 2019. Udmurty Chainskogo rayona Tomskoy oblasti: etnokul'turnaya i yazykovaya situatsiya v nachale XXI veka. - Tomskiy zhurnal lingvisticheskikh $i$ antropologicheskikh issledovaniy (Tomsk Journal of Linguistics and Anthropology): 42-50. [Мымрина, Дина Ф. и Ольга А. Шитц. 2019. Удмурты Чаинского района Томской области: этнокультурная и языковая ситуация в начале XXI века. -Томский журнал лингвистических и антропологических исследований (Tomsk Journal of Linguistics and Anthropology): 42-50.] DOI: https://doi.org/10.23951/2307-6119-2019-3-25-42-50.

Shakhov, Pavel S. 2017. Mordovskiy kalendarno-obryadovyy fol'klorno-etnograficheskiy kompleks sibirskogo bytovaniya (vesenne-letniy period). - Sibirskiy filologicheskiy zhurnal 1: 261276. [Шахов, Павел С. 2017. Мордовский календарно-обрядовый фолькдорно-этнографический комплекс сибирского бытования (весенне-летний период). - Сибирский филологический журнал 1: 261-276.] DOI: https://doi.org/10.17223/18137083/58/25.

Tuchkova, Natal'ya A. 2001. Tiginskiye udmurty. - Zemlya Chainskaya: sbornik nauchno-populyarnykh ocherkov k 100-letiyu s. Podgornogo. Tomsk: Izdatel'stvo Tomskogo universiteta: 170189. [Тучкова, Наталья А. 2001. Тигинские удмурты. - Земля Чаинская: сборник научно-популярных очерков к 100-летию с. Подгорного. Томск: Издательство Томского университета: 170-189.] 
Vanishing Voices = Vanishing Voices from Russia and Eastern Europe. - British Library. https:// sounds.bl.uk/World-and-traditional-music/Vanishing-voices-from-the-Uralic-world (accessed April 20, 2020).

Vereshchagin, Grigoriy Ye. 1886. Votyaki Sosnovskogo kraya. Sankt-Peterburg. [Верещагин, Григорий Е. 1886. Вотяки Сосновского края. Санкт-Петербург.]

Vladykin, Vladimir Ye. 1976. Sibirskaya gruppa udmurtov. - Etnicheskaya istoriya narodov Urala i Povolzh'ya: (Prepr. dokl. i soobshch). Ufa: 28-30. [Владыкин, Владимир Е. 1976. Сибирская группа удмуртов. - Этническая история народов Урала и Поволжья: (Препр. докл. и сообщ). Уфа: 28-30.]

Vladykin, Vladimir Ye. 1976. Religiozno-mifologicheskaya kartina mira. Izhevsk: Udmurtiya. [Владыкин, Владимир Е. 1994. Религиозно-мифологическая картина мира. Ижевск: Удмуртия.]

Vladykina, Tat'yana G. 1997. Udmurtskiy fol'klor: problemy zhanrovoy evolyutsii i sistematiki. Izhevsk: Udmurtskiy institut istorii, yazyka i literatury Ural'skogo otdeleniya Rossiyskoy akademii nauk. [Владыкина, Татьяна Г. 1997. Удмуртский фольклор: проблемы жанровой әволюции и систематики. Ижевск: Удмуртский институт истории, языка и литературы Уральского отделения Российской академии наук.]

Zhuravlëva, Alevtina N. and Roza A. Kuznetsova. 2008. Sto let rasstavaniya. - Fenomen Udmurtii 8. Udmurtskaya diaspora. Moskva-Izhevsk: Udmurtiya: 201-211. [Журавлёва, Алевтина Н. и Роза А. Кузнецова. 2008. Сто лет расставания. - Феномен удмуртии 8. удмуртская диаспора. Москва-Ижевск: Удмуртия: 201-211.] 